\title{
Evaluation of Angiogenic Factors (PIGF and sFlt-1) in Pre-eclampsia Diagnosis
}

\section{Avaliação dos fatores angiogênicos (PIGF e sFlt-1) no diagnóstico de pré-eclâmpsia}

\author{
Catherine Primo Nogueira de Sá1,2,3(-) Mirela Foresti jiménez ${ }^{1,2(1)}$ Marcos Wengrover Rosa 3 \\ Ellen Machado Arlindo 1,2,3(-) Antonio Celso Koehler Ayub ${ }^{1,2(0)}$ Rodrigo Bernardes Cardoso ${ }^{1,2(1)}$ \\ Régis Kreitchmann ${ }^{1,20}$ Patrícia El Beitune ${ }^{1,2}$ (1)
}

${ }^{1}$ Department of Gynecology and Obstetrics, Universidade Federal de
Ciências da Saúde, Porto Alegre, RS, Brazil
2 Obstetrics Service, Santa Casa de Misericórdia, Porto Alegre, RS, Brazil
${ }^{3}$ Obstetrics Service, Hospital Moinhos de Vento, Porto Alegre, RS, Brazil
Address for correspondence Catherine Primo Nogueira de Sá, MD, MSc, Rua Félix da Cunha, 737 / 702, Porto Alegre, RS, 90570-001, Brazil

(e-mail: cathynogueira@yahoo.com.br).

Rev Bras Ginecol Obstet 2020;42(11):697-704.

\begin{abstract}
Keywords

- angiogenic factors

- pre-eclampsia

- PIGF

- protein creatinine ratio

- sFlt-1
\end{abstract}

Resumo
Objective Recent observations support the hypothesis that an imbalance between angiogenic factors has a fundamental role in the pathogenesis of pre-eclampsia and is responsible for the clinical manifestations of the disease. The goal of the present study was to evaluate the sensitivity, specificity, and the best accuracy level of Soluble fms-like tyrosine kinase-1 (sFlt-1), placental growth factor (PIGF), and sFlt-1/PIGF ratio in maternal serum and protein/creatinine ratio in urine sample to define the best cutoff point of these tests to discriminate between the patients with gestational hypertension and the patients with pre-eclampsia, to evaluate the possibility of using them as diagnostic methods.

Methods A prospective longitudinal study was performed, and blood samples were collected from 95 pregnant patients with hypertension to measure serum concentrations of biomarkers sFlt-1 and PIGF. Urine samples were collected for protein screening. Significance was set as $p<0.05$.

Results The sFlt-1/PIGF ratio demonstrated a sensitivity of $57.5 \%$ and a specificity of $60 \%$ using 50.4 as a cutoff point. The test that showed the best accuracy in the diagnosis of pre-eclampsia was protein/creatinine ratio, with a sensitivity of $78.9 \%$ and a specificity of $70 \%$ using 0.4 as a cutoff point and showing an area under the receiver operating characteristic curve of $0.80(p<0.001)$.

Conclusion No studied laboratory test proved to be fairly accurate for the diagnosis of pre-eclampsia, except for the protein/creatinine ratio. The evidence is insufficient to recommend biomarkers sFlt- 1 and PIGF to be used for the diagnosis of pre-eclampsia.

Objetivo Pesquisas recentes sustentam a hipótese de que um desequilíbrio entre fatores angiogênicos desempenhe um papel fundamental na patogênese da préeclâmpsia e seja responsável pelas manifestações clínicas da doença. O objetivo do presente estudo foi avaliar a sensibilidade, a especificidade e o nível de melhor acurácia received

December 10, 2019

accepted

May 28, 2020
DOI https://doi.org/

10.1055/s-0040-1713916. ISSN 0100-7203.
Copyright $\odot 2020$ by Thieme Revinter

Publicações Ltda, Rio de Janeiro, Brazil
License terms

(c) (9) 


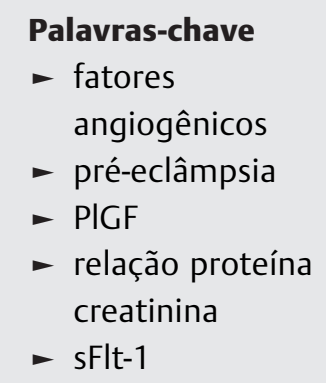

do Fator semelhante a tirosina quinase 1 (sFlt-1), Fator de crescimento placentário (PIGF), e relação sFlt-1/PIGF no soro materno e relação proteína/creatinina em amostra de urina e definir o melhor ponto de corte desses testes para distinguir pacientes com hipertensão gestacional daquelas com pré-eclâmpsia, a fim de avaliar a possibilidade de utilizá-los como métodos diagnósticos.

Métodos Foi realizado um estudo prospectivo longitudinal e foram coletadas amostras de sangue de 95 gestantes com hipertensão arterial para dosar as concentrações séricas dos biomarcadores sFlt-1 e PIGF. Amostras de urina foram coletadas para pesquisa de proteinúria. Foram consideradas significativas as diferenças com $p<0,05$. Resultados A relação sFlt-1/PIGF demonstrou sensibilidade de $57,5 \%$ e especificidade de $60 \%$ utilizando 50,4 como ponto de corte. $O$ teste que apresentou a melhor acurácia no diagnóstico de pré-eclâmpsia foi a relação proteína/creatinina, com sensibilidade de $78,9 \%$ e especificidade de $70 \%$, utilizando 0,4 como ponto de corte e demostrando uma área sob a curva receiver operating characteristic (ROC, na sigla em inglês) de 0,80 $(p<0,001)$.

Conclusão Nenhum método de rastreamento isolado se mostrou com boa acurácia para o diagnóstico de pré-eclâmpsia, exceto a relação proteína/creatinina. As evidências são insuficientes para recomendar os biomarcadores sFlt-1 e PIGF como diagnóstico de pré-eclâmpsia.

\section{Introduction}

The hypertensive disorders of pregnancy are a leading cause of maternal and perinatal mortality and morbidity worldwide, especially in developing countries, affecting $10 \%$ of pregnancies, and have been responsible for high costs to the health system. ${ }^{1-3}$ Pre-eclampsia and gestational hypertension are characterized by the new onset of hypertension ( $>140 \mathrm{~mm}$ $\mathrm{Hg}$ systolic or $>90 \mathrm{~mm} \mathrm{Hg}$ diastolic) after 20 weeks of gestation. The next step is to define whether this represents pure gestational hypertension or pre-eclampsia. Pre-eclampsia is diagnosed by hypertension and the coexistence of one or more of the following conditions: proteinuria (urine protein/ creatinine $>0.3 \mathrm{mg} / \mathrm{mg}$ or $>300 \mathrm{mg} /$ day); maternal organ dysfunction (renal insufficiency, liver involvement, neurological complications, hematological complications); and uteroplacental dysfunction (fetal growth restriction) ${ }^{4,5}$ Although often accompanied by new onset proteinuria, hypertension and other signs or symptoms of pre-eclampsia may present in some women in the absence of proteinuria. ${ }^{6}$

The pathogenesis of pre-eclampsia involves deficient trophoblast invasion that is responsible for altered uterine blood flow and placental oxidative stress. ${ }^{7}$ Recent observations support the hypothesis that altered expression of placental antiangiogenic factors is responsible for the clinical manifestations of the disease. The damaged placenta produces higher concentrations of Soluble fms-like tyrosine kinase- 1 (sFlt- 1 ), a soluble receptor for vascular endothelial growth factor (VEGF) and placental growth factor (PIGF) that is released into the maternal circulation and is involved in endothelial dysfunction. ${ }^{8-11}$ Soluble fms-like tyrosine kinase- 1 is an endogenous antiangiogenic protein that is made by the placenta and acts by binding and neutralizing the proangiogenic proteins VEGF and PIGF. Decreased concentrations of the circulating proangio- genic factor PlGF and increased concentrations of the antiangiogenic factor sFlt- 1 have been observed in pre-eclamptic patients, suggesting that an imbalance between these factors has a fundamental role in the pathogenesis of pre-eclampsia. ${ }^{12-14}$ Thereby, both sFlt- 1 and PIGF have been suggested to be useful for the diagnosis of pre-eclampsia.

The goal of the present study was to evaluate the sensitivity, specificity, and the best accuracy level of sFlt-1, PIGF, sFlt-1/ PIGF ratio in maternal serum and protein/creatinine ratio in urine sample to define the best cutoff point of these tests to discriminate between the patients with gestational hypertension and the patients with pre-eclampsia, to evaluate the possibility of using them as diagnostic methods. In addition, we evaluated the degree of association of 24-hour proteinuria with sFlt-1, PIGF, sFlt-1/PIGF ratio and protein/creatinine ratio.

\section{Methods}

A prospective longitudinal study evaluated 95 pregnant women with hypertension in attendance at prenatal clinics and at the obstetric emergency of a tertiary university hospital in the south of Brazil (Maternidade Mário Totta - Santa Casa de Misericórdia de Porto Alegre, state of Rio Grande do Sul, Brazil) over a period of 12 months (October 2010 to October 2011). All included patients signed an informed consent form. The present study was approved by the Institutional Review Board (CEP UFCSPA 10-628).

The present study included pregnant women after 20 weeks of gestation with systolic blood pressure $\geq 140 \mathrm{~mm}$ $\mathrm{Hg}$ or diastolic blood pressure $\geq 90 \mathrm{~mm} \mathrm{Hg}$, measured according to a standard protocol, ${ }^{15,16}$ and with $\geq 1$ occurrences of protein on a dipstick or a protein/creatinine ratio $\geq 40 \mathrm{mg} / \mathrm{mmol}$. These tests were considered screening methods. Thus, patients with positive screening had 24-hour 
proteinuria collection to confirm or exclude pre-eclampsia, considering this test as the evaluation parameter used in our institution for the diagnosis of the disease. Thereby, the 24-hour proteinuria was used to stratify patients into two groups, gestational hypertension and pre-eclampsia. The 24-hour collection was performed during hospitalization of the patient, under supervision of the nursing staff, following standard procedures established by institutional guidelines, which contributes to more accurate results. We excluded patients with diabetes mellitus and vascular disease prior to the pregnancy or preexisting kidney disease.

Blood samples were collected and serum concentrations of sFlt- 1 and PlGF were measured at the time of the diagnosis. The Elecsys (Roche Diagnostics Brazil São Paulo, SP, Brazil) immunoassays for determination of sFlt- 1 and PIGF and analysis of blood samples were performed at the central laboratory of the Santa Casa. Clinical information was verified through data collection during hospitalization, searching for maternal and gestational data, risk factors, gestational prognosis (eclampsia and HELLP Syndrome), and other relevant evaluation parameters (hyperuricemia, severe hypertension, proteinuria $\geq 5 \mathrm{~g}$, fetal growth restriction). We made a separate analysis with the primigravida group. In addition, patients were stratified into two groups, early-onset pre-eclampsia ( $<34$ weeks of gestation) and late-onset pre-eclampsia ( $\geq 34$ weeks of gestation).

The quantitative variables were described by mean and standard deviation (SD), or median and interquartile range (IQR). To compare averages between groups, the $t$-test was applied. For asymmetric variables, we used the Mann Whitney test. To compare proportions, the chi-squared test or the Fisher exact test was applied. Serum levels of sFlt- 1 and PIGF, as well as biochemical parameters, were evaluated for sensitivity, specificity, and the optimal cutoff point by receiver operating characteristic (ROC) curve. The Spearman correlation coefficient $(r)$ was used to evaluate the degree of association between the tests. Sample size was calculated considering an $\alpha$ of 0.05 and a $\beta$ of 0.20 and setting the null hypothesis in an area under the ROC curve of 0.75 . A total of 75 patients were necessary. Statistical analysis was performed using PASW Statistics for Windows, Version 18 (SPSS Inc., Chicago, IL, USA) and the significance level adopted was 0.05 .

\section{Results}

- Table 1 shows maternal and gestational data, risk factors (chronic/preexisting hypertension, pre-eclampsia in a previous

Table 1 Sample characterization of patients included in the study

\begin{tabular}{|c|c|c|c|c|}
\hline \multirow{2}{*}{$\frac{\text { Variables* }^{*}}{\text { Demographic data }}$} & \multicolumn{4}{|c|}{ Total Sample $(n=93)$ Pre-eclampsia $(n=73)$ Gestational Hypertension $(n=20) p$-value } \\
\hline & & & & \\
\hline Maternal age (years old) & $29.1 \pm 7.7$ & $29.5 \pm 7.7$ & $27.9 \pm 7.8$ & 0.422 \\
\hline Body mass index $\left(\mathrm{kg} / \mathrm{m}^{2}\right)$ & $34.0 \pm 6.7$ & $34.1 \pm 7.1$ & $33.3 \pm 4.4$ & 0.666 \\
\hline \multicolumn{5}{|l|}{ Gestational data } \\
\hline Gestational age at diagnosis (weeks) & $34.2 \pm 4.0$ & $34.2 \pm 4.4$ & $34.1 \pm 2.5$ & 0.915 \\
\hline Nulliparity & $39(41.9)$ & $31(42.5)$ & $8(40.0)$ & 1.000 \\
\hline \multicolumn{5}{|l|}{ Risk factors } \\
\hline Chronic/preexisting hypertension & $42(45.2)$ & $34(46.6)$ & $8(40.0)$ & 0.787 \\
\hline \multicolumn{2}{|c|}{ Preeclampsia in a previous pregnancy6 (6.5) } & $5(6.8)$ & $1(5.0)$ & 1.000 \\
\hline Family history of preeclampsia & $3(3.2)$ & $3(4.1)$ & $0(0.0)$ & 1.000 \\
\hline \multicolumn{5}{|l|}{ Evaluation parameters } \\
\hline Uric acid $\geq 6 \mathrm{mg} / \mathrm{dL}$ & $22(23.9)$ & $18(24.7)$ & $4(21.1)$ & 1.000 \\
\hline Severe blood pressure elevation & $47(50.5)$ & $38(52.1)$ & $9(45.0)$ & 0.759 \\
\hline Proteinuria $\geq 5 \mathrm{~g}$ in 24 hours & $1(1.5)$ & $1(2.0)$ & $0(0.0)$ & 1.000 \\
\hline Fetal growth restriction & $12(12.9)$ & $8(11.0)$ & $4(20.0)$ & 0.280 \\
\hline \multicolumn{5}{|l|}{ Laboratory tests } \\
\hline Protein/creatinine (mg/mmol) & $0.47(0.36-0.96)$ & $0.54(0.41-1.13)$ & $0.33(0.24-0.42)$ & $<0.001$ \\
\hline Protein/creatinine ratio $\geq 0.4$ & $62(68.9)$ & $56(80.0)$ & $6(30.0)$ & $<0.001$ \\
\hline Positive preeclampsia screening & $70(75.3)$ & $60(82.2)$ & $10(50.0)$ & 0.007 \\
\hline 24-hour proteinuria (g) & $0.37(0.29-0.57)$ & $0.46(0.34-0.64)$ & $0.21(0.15-0.27)$ & $<0.001$ \\
\hline $\mathrm{PIGF}(\mathrm{pg} / \mathrm{mL})$ & $100(62.3-235)$ & 97.7 (62.3-235) & 119 (56.7-283) & 0.495 \\
\hline sFlt-1 (pg/mL) & $5253(2649-9071)$ & 5469 (2703-9375) & $3920(1613-8574)$ & 0.169 \\
\hline sFlt-1/PIGF ratio & $55.3(14.7-113)$ & $58.7(16.5-122)$ & $34.3(6.5-95.5)$ & 0.258 \\
\hline Uric acid (mg/dL) & $5.16 \pm 1.30$ & $5.21 \pm 1.30$ & $4.97 \pm 1.31$ & 0.475 \\
\hline
\end{tabular}

Abbreviations: P1GF, placental growth factor; sFlt-1, Soluble fms-like tyrosine kinase-1.

*described by mean \pm standard deviation, median (percentiles $25-75$ ) or $\mathrm{n}(\%)$. 
700 Evaluation of Angiogenic Factors (PIGF and sFlt-1) in Preeclampsia Diagnosis Sá et al.

Table 2 Evaluation of the best cutoff point and the area under the ROC curve of the studied tests for the diagnosis of preeclampsia, with their sensitivity and specificity

\begin{tabular}{lllllll}
\hline Tests & Sensitivity & Specificity & Cutoff point & AUC ROC & 95\%Cl & $p$-value \\
\hline sFlt-1/PIGF & 57.5 & 60.0 & $>50.4$ & 0.58 & $0.44-0.73$ & 0.258 \\
sFlt-1 & 61.6 & 60.0 & $>4671$ & 0.60 & $0.46-0.74$ & 0.169 \\
PIGF & 57.5 & 60.0 & $<104.1$ & 0.55 & $0.41-0.69$ & 0.495 \\
Protein/creatinine & 78.9 & 70.0 & $>0.40$ & 0.80 & $0.68-0.92$ & $<0.001$ \\
\hline
\end{tabular}

Abbreviations: AUC, area under the curve; $\mathrm{Cl}$, confidence interval; P1GF, placental growth factor; ROC, receiver operating characteristic; sFlt-1, Soluble fms-like tyrosine kinase-1.

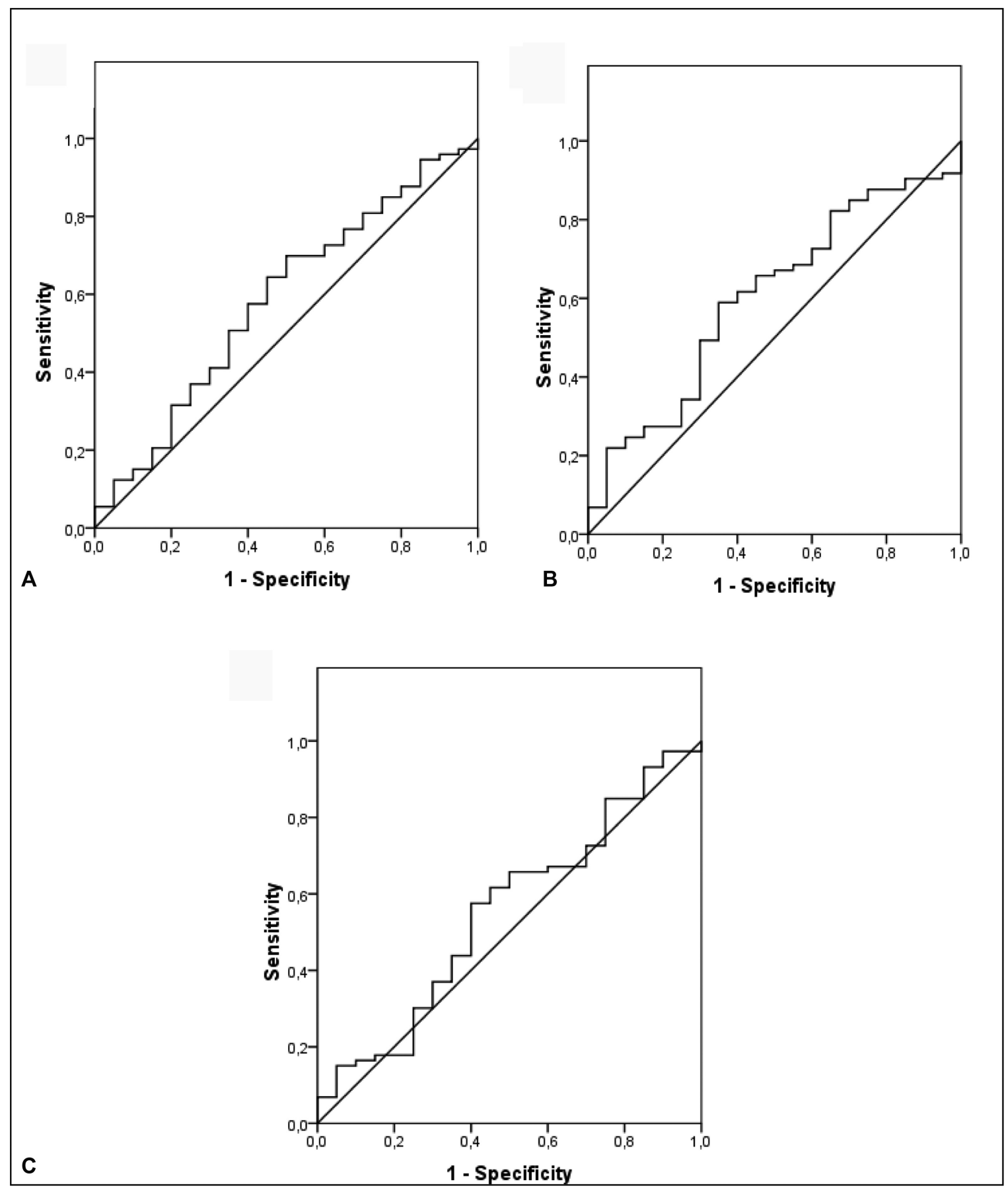

Fig. 1 ROC curve of sFlt-1/PIGF ratio (A), sFlt-1 (B) and PIGF (C) in the diagnosis of preeclampsia. 
pregnancy and family history of pre-eclampsia) and some relevant evaluation parameters (uric acid $>6 \mathrm{mg} / \mathrm{dL}$, systolic blood pressure $\geq 160 \mathrm{~mm} \mathrm{Hg}$ or diastolic blood pressure $\geq 110 \mathrm{~mm} \mathrm{Hg}$, proteinuria $>5 \mathrm{~g}$ in 24 hours and fetal growth restriction). Besides, we can observe the screening methods, biomarkers sFlt-1 and PIGF, and 24-hour proteinuria levels. A total of 95 pregnant patients had blood samples collected to measure serum concentrations of biomarkers sFlt- 1 and PIGF. One patient has been excluded from the analysis because there was no screening test performed, and another patient has been excluded because there was no registered value of PIGF. Thus, the statistical analysis included 93 pregnant patients with hypertension.

Pre-eclampsia was confirmed in 73 patients (78.5\%). A total of 29 (39.7\%) patients had early-onset pre-eclampsia and 44 (60.3\%) had late-onset disease. When evaluating the preeclampsia group and the gestational hypertension group, there was no association with nulliparity and no significant difference between early or late-onset pre-eclampsia. Only one patient developed eclampsia and HELLP syndrome (1.1\%). Most of the pregnant patients were in the $3^{\text {rd }}$ trimester when they entered in the study, justifying higher values for the body mass index (BMI), which was calculated at the moment the patient was included and not in the beginning of pregnancy.

We analyzed laboratory tests individually and could observe a significant association of protein/creatinine ratio and 24-hour proteinuria with the diagnosis of pre-eclampsia. The biomarkers sFlt-1 and PlGF did not have a good accuracy for disease diagnosis. Demographic and gestational data, risk factors and other evaluation parameters did not have a significant association with pre-eclampsia in our study.

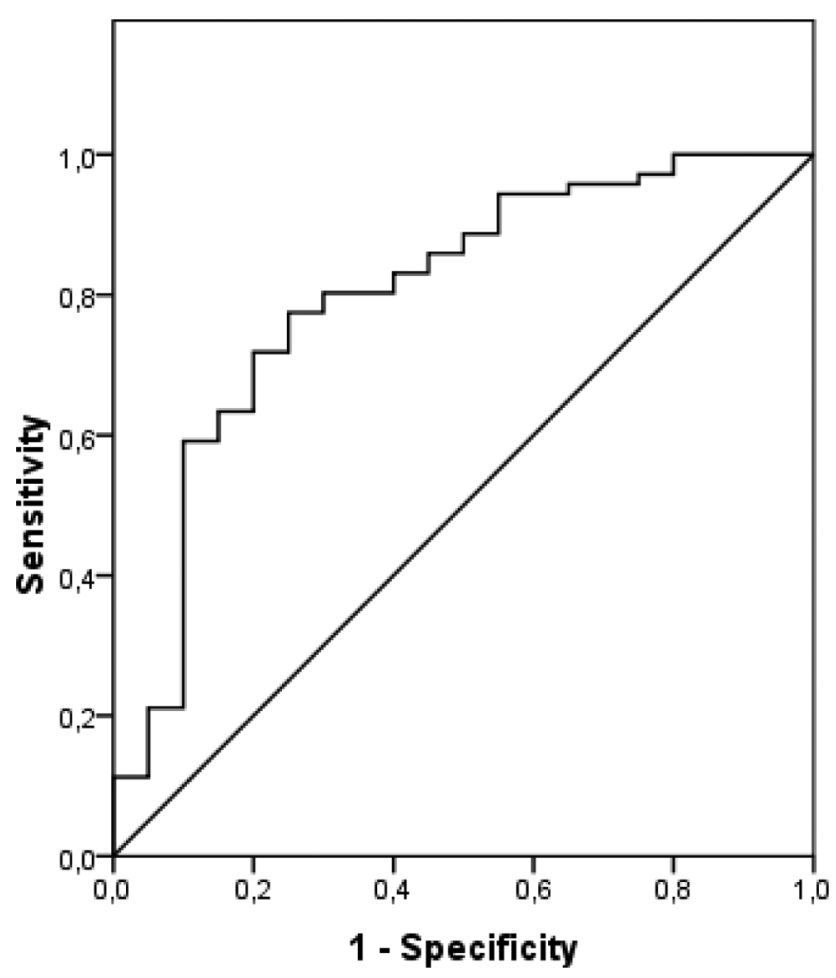

Fig. 2 ROC curve of protein/creatinine ratio in preeclampsia diagnosis.
We determined the sensitivity and the specificity for different thresholds of a parameter, defining the best cutoff point for each test. Calculating the area under the ROC curve, we evaluated the performance of the studied tests ( - Table 2 ). The sFlt- 1 / PIGF ratio demonstrated a sensitivity of $57.5 \%$ and a specificity of $60 \%$ using 50.4 as a cutoff point. The protein/creatinine ratio showed the best sensitivity (78.9\%) and specificity (70\%) using 0.4 as a cutoff point and was the test with the best accuracy level in pre-eclampsia diagnosis, showing an area under the ROC curve of $0.80(p<0.001)$. In - Figs. 1 and 2 , the sensitivity, specificity and the area under the ROC curve for the sFlt-1, PIGF, sFlt-1/PIGF ratio and protein/creatinine ratio can be observed.

We used Spearman correlation to evaluate the degree of association between 24-hour proteinuria with sFlt-1, PIGF, sFlt-1/PIGF ratio and protein/creatinine ratio. For sFlt-1 (rs= $0.175 ; p=0.163$ ), PIGF ( $\mathrm{rs}=-0.066 ; p=0.599$ ) and sFlt- $1 /$ $\mathrm{PIGF}$ ( $\mathrm{rs}=0.107 ; p=0.396$ ), there was no degree of association. The only test that showed significant association with 24-hour proteinuria was protein/creatinine ratio, with a regular association $(\mathrm{rs}=0.403 ; p=0.001)$.

\section{Discussion}

Several studies have evaluated the role of biochemical markers or a combination of biochemical and biophysical markers in the prediction of pre-eclampsia in the $1^{\text {st }}$ and $2^{\text {nd }}$ trimesters of pregnancy. Clinical, ultrasonographic, and laboratory parameters have been explored during early pregnancy as tools for predicting who will later develop preeclampsia. None of these, individually, have sufficient sensitivity and predictive values to be useful clinically, even among women at increased risk. ${ }^{17-21}$ Regardless of the parameters used, screening for pre-eclampsia in low-risk women is associated with very low positive predictive values ranging from 8 to $33 \%{ }^{22}$

The most studied antiangiogenic and proangiogenic markers have been sFlt-1 (soluble receptor for VEGF and PIGF) and PIGF. Studies show that lower concentrations of PlGF and higher concentrations of sFlt-1 during pregnancy confer an increased risk for the subsequent development of pre-eclampsia. Some have noted that maternal serum concentrations of these factors significantly separated healthy pregnant women and women with pre-eclampsia, showing the value of these markers in the prediction of pre-eclampsia and in the differential diagnosis of patients with atypical presentations of the disease. In addition, in high-risk women, the sFlt$1 /$ PlGF ratio is altered prior to pre-eclampsia onset. ${ }^{23-26}$

Recent studies have evaluated the performance of a newly developed assay for biomarkers PIGF and sFlt-1, which has been studied for the prediction, diagnosis and prognosis of patients with pre-eclampsia. A study conducted by Hagmann et $\mathrm{al}^{27}$ showed that in early onset pre-eclampsia, the sFlt-1/ PIGF ratio changes 11 weeks before delivery. Zeisler et $\mathrm{al}^{28}$ observed that a sFlt- $1 / \mathrm{PlGF}$ ratio $<38$ rules out pre-eclampsia, irrespective of gestational age, for at least 1 week. In women with an elevated sFlt-1/PIGF ratio $>85$ (early-onset pre-eclampsia) or $>110$ (late-onset pre-eclampsia), the diagnosis of pre-eclampsia or placenta related disorders is 
highly likely. Severely elevated sFlt-1/PIGF ratios ( $>655$ at $<34$ weeks; $>201$ at $\geq 34$ weeks) are associated closely with the need to deliver within 48 hours. $^{29}$

Many studies evaluated biomarkers for the prediction of pre-eclampsia. Different from those studies, we evaluated angiogenic factors for the purpose of diagnostic correlation with pre-eclampsia. In a longitudinal prospective study, with adherence to methodological criteria, reviewed in detail, excluding any pregnant woman who could be configured to bias the results analysis, we studied the role of biomarkers PIGF and sFlt-1 in the diagnostic of pre-eclampsia. The present study demonstrated the cutoff point for PlGF (104.1) and for sFlt-1 (4671). Considering these biomarkers, the sFlt-1/PIGF ratio revealed the best association with preeclampsia diagnosis using 50.4 as a cutoff point. However, our results showed that sFlt-1, PlGF, and sFlt-1/PIGF ratio did not have good diagnostic accuracy.

Although the literature presents favorable evidence, there are many controversies on the benefits that these biomarkers may provide in the assessment of pre-eclampsia. A study conducted at Cambridge University showed that higher levels of sFlt- 1 were not associated with the risk of pre-eclampsia but were associated with a reduced risk of delivery of a small for gestational age infant, spontaneous preterm birth, and stillbirth associated with abruption or growth restriction. ${ }^{30} \mathrm{~A}$ case-control study showed that sFlt- 1 levels had low capacity to discriminate between healthy patients and pre-eclampsia patients. ${ }^{31}$ A systematic review accomplished at Oxford University demonstrated that a $3^{\text {rd }}$ trimester increase in sFlt- 1 and decrease in PIGF levels were associated with pre-eclampsia, specifically severe disease; however, the authors concluded that the evidence is insufficient to recommend these biomarkers to be used for screening. ${ }^{32}$

The most reasonable conclusions seem to be that determination of sFlt-1/PIGF ratio can serve as an aid in the diagnosis of hypertensive disorders in pregnancy. The performance of maternal levels of these factors, especially on early onset pre-eclampsia, could be further improved by combining several markers. Combining biomarkers with maternal history, mean blood pressure and uterine artery Doppler achieves a detection rate of $\sim 90 \%$ of cases to develop pre-eclampsia. ${ }^{33}$

Some important considerations of our study are presented below. When our study was initiated, in October 2010, the protein/creatinine ratio was considered a screening method. Thus, pregnant women with positive screening $(\geq 1$ on dipstick or protein/creatinine ratio $\geq 40 \mathrm{mg} / \mathrm{mmol}$ ) were considered inclusion criteria of the study, requiring the 24-hour proteinuria collection to define or exclude the diagnosis of preeclampsia. We used a cutoff level of $0.4 \mathrm{mg} / \mathrm{mg}$ for protein/creatinine ratio according to previous studies performed at our institution, because this cutoff point showed the best accuracy level for pre-eclampsia screening in our pregnant women population. Midrange protein/creatinine ratio $(0.3 \mathrm{mg} / \mathrm{mg})$ had poor sensitivity and specificity in our study. In another hospital, located in the same city of our study, they found that hypertensive pregnant women with a protein/creatinine ratio $\geq 0.3 \mathrm{mg} / \mathrm{mg}$ had worse maternal and perinatal outcomes than those with a protein/creatinine ratio $<0.3 \mathrm{mg} / \mathrm{mg} .{ }^{34}$ The latest guidelines already consider the use of protein/creatinine ratio as part of criteria for the diagnosis of pre-eclampsia, but many authors and institutions continue to use and consider a full 24-hour urine test for accurate results. ${ }^{35}$ The existing evidence is not, however, sufficient to determine how the protein/creatinine ratio should be used in clinical practice, owing to the heterogeneity in test accuracy and prevalence across studies. ${ }^{36}$

We made a separate analysis with the primigravida group to assess the correlation with the diagnosis of pre-eclampsia; however, in our study, there was no association with nulliparity. Besides, patients were stratified into 2 groups, earlyonset pre-eclampsia ( $<34$ weeks of gestation) and late-onset pre-eclampsia ( $\geq 34$ weeks of gestation) and, similarly, there was no significant difference between the groups. Maybe these associations could be observed if we had a larger sample.

Although some criteria are currently no longer considered as severity, when analyzed together, they may have clinical significance. Therefore, we evaluated hyperuricemia, severe hypertension, proteinuria $\geq 5 \mathrm{~g}$ and fetal growth restriction as relevant parameters. The evaluation of these parameters did not show a significant difference when comparing preeclampsia and gestational hypertension. Twenty-four-hour proteinuria $>5 \mathrm{~g}$ has not been considered as a maternal prognosis to indicate pregnancy resolution. ${ }^{6}$

The BMI was calculated at the entry of the study, not in the beginning of the pregnancy, justifying higher values for this ratio. Furthermore, as the sample comprises hypertensive pregnant women, we could observe higher values for the $\mathrm{BMI}$, since obesity is a risk factor for hypertension. Moreover, in recent decades, there has been an increase in weight in the general population. The growing prevalence of obesity is increasingly recognized as one of the most important risk factors for the development of hypertension. ${ }^{37}$

Concluding, we can observe that there is considerable heterogeneity among reports. There are differences in the analyte and storage conditions, in the gestational periods selected for blood sampling, and in inclusion and exclusion criteria. Some reports include women with risk factors for pre-eclampsia, whereas others excluded this group; some of the study population was exclusively nulliparous women, whereas all parities were included in others. The evidence is neither strong enough nor sufficient to recommend PIGF and sFlt-1 to be used for pre-eclampsia diagnosis or to screen women at risk to develop the disease. Therefore, the use of proangiogenic and antiangiogenic factors in the assessment of pre-eclampsia is a subject of controversy and is currently under investigation. Prospective studies employing rigorous laboratory and study design criteria are needed to determine the clinical usefulness of these tests.

\section{Conclusion}

In summary, in our research, no studied laboratory test proved to be fairly accurate for the diagnosis of pre-eclampsia, except for the protein/creatinine ratio. The evidence is insufficient to recommend sFlt- 1 and PIGF to be used for the diagnosis of preeclampsia. The identification of biomarkers that can 
contribute to early detection of pre-eclampsia is essential to apply better surveillance and treatment protocols. Besides, demonstrating the clinical utility of these angiogenic markers could affect the management decisions of the obstetrician, improve health outcomes, and reduce costs to the healthcare system.

\section{Contributors}

All authors contributed with the project and data interpretation, the writing of the article, the critical review of the intellectual content, and with the final approval of the version to be published.

\section{Conflict of Interests}

The authors have no conflict of interests to declare.

\section{Acknowledgments}

We would like to thank Roche Diagnostics Brazil for providing the Elecsys immunoassays for the determination of biomarkers sFlt- 1 and PIGF.

\section{References}

1 World Health Organization. The World Health Report 2005: make every mother and child count [Internet]. Geneva: WHO; 2005 [cited 2019 Nov 17]. Available from: https://www.who.int/whr/ 2005/whr2005_en.pdf?ua=1

2 American College of Obstetricians and Gynecologists; Task Force on Hypertension in Pregnancy. Hypertension in pregnancy. Report of the American College of Obstetricians and Gynecologists' Task Force on Hypertension in Pregnancy. Obstet Gynecol. 2013;122(05): 1122-1131. Doi: 10.1097/01.AOG.0000437382.03963.88

3 Duley L. The global impact of pre-eclampsia and eclampsia. Semin Perinatol. 2009;33(03):130-137. Doi: 10.1053/j.semperi.2009. 02.010

4 Magee LA, Pels A, Helewa M, Rey E, von Dadelszen P; Canadian Hypertensive Disorders of Pregnancy (HDP) Working Group; Canadian Hypertensive Disorders of Pregnancy HDP Working Group. The hypertensive disorders of pregnancy (29.3). Best Pract Res Clin Obstet Gynaecol. 2015;29(05):643-657. Doi: 10.1016/j. bpobgyn.2015.04.001

5 Tranquilli AL, Dekker G, Magee L, Roberts J, Sibai BM, Steyn W, et al. The classification, diagnosis and management of the hypertensive disorders of pregnancy: A revised statement from the ISSHP. Pregnancy Hypertens. 2014;4(02):97-104. Doi: 10.1016/j. preghy.2014.02.001

6 American College of Obstetricians and Gynecologists. ACOG Practice Bulletin No. 202: gestational hypertension and preeclampsia. Obstet Gynecol. 2019;133(01):e1-e25. Doi: 10.1097/AOG.000000000000 3018

7 de Oliveira LG, Karumanchi A, Sass N. [Preeclampsia: oxidative stress, inflammation and endothelial dysfunction]. Rev Bras Ginecol Obstet. 2010;32(12):609-616. Doi: 10.1590/S010072032010001200008

8 Kopcow HD, Karumanchi SA. Angiogenic factors and natural killer (NK) cells in the pathogenesis of preeclampsia. J Reprod Immunol. 2007;76(1-2):23-29. Doi: 10.1016/j.jri.2007.03.018

9 Silasi M, Cohen B, Karumanchi SA, Rana S. Abnormal placentation, angiogenic factors, and the pathogenesis of preeclampsia. Obstet Gynecol Clin North Am. 2010;37(02):239-253. Doi: 10.1016/j. ogc.2010.02.013

10 Wang A, Rana S, Karumanchi SA. Preeclampsia: the role of angiogenic factors in its pathogenesis. Physiology (Bethesda). 2009;24:147-158. Doi: 10.1152/physiol.00043.2008
11 Lam C, Lim KH, Karumanchi SA. Circulating angiogenic factors in the pathogenesis and prediction of preeclampsia. Hypertension. 2005; 46(05):1077-1085. Doi: 10.1161/01.HYP.0000187899.34379.b0

12 Maynard SE, Karumanchi SA. Angiogenic factors and preeclampsia. Semin Nephrol. 2011;31(01):33-46. Doi: 10.1016/j.semnephrol. 2010.10.004

13 Maynard S, Epstein FH, Karumanchi SA. Preeclampsia and angiogenic imbalance. Annu Rev Med. 2008;59:61-78. Doi: 10.1146/ annurev.med.59.110106.214058

14 Kulkarni AV, Mehendale SS, Yadav HR, Kilari AS, Taralekar VS, Joshi SR. Circulating angiogenic factors and their association with birth outcomes in preeclampsia. Hypertens Res. 2010;33(06): 561-567. Doi: 10.1038/hr.2010.31

15 Alpert B, McCrindle B, Daniels S, Dennison B, Hayman L, Jacobson M, et al; Atherosclerosis, Hypertension, and Obesity in the Young Committee of the American Heart Association Council on Cardiovascular Disease in the Young. Recommendations for blood pressure measurement in human and experimental animals; part 1: blood pressure measurement in humans. Hypertension. 2006;48(01):e3, author reply e5. Doi: 10.1161/01.HYP.0000229661.06235.08

16 Report of the National High Blood Pressure Education Program Working Group on High Blood Pressure in Pregnancy. Am J Obstet Gynecol. 2000;183(01):S1-S22. Doi: 10.1067/mob.2000.107928

17 Baweja S, Kent A, Masterson R, Roberts S, McMahon LP. Prediction of pre-eclampsia in early pregnancy by estimating the spot urinary albumin: creatinine ratio using high-performance liquid chromatography. BJOG. 2011;118(09):1126-1132. Doi: 10.1111/ j.1471-0528.2011.02960.x

18 Kleinrouweler CE, Wiegerinck MMJ, Ris-Stalpers C, Bossuyt PMM, van der Post JAM, von Dadelszen P, et al; EBM CONNECT Collaboration. Accuracy of circulating placental growth factor, vascular endothelial growth factor, soluble fms-like tyrosine kinase 1 and soluble endoglin in the prediction of pre-eclampsia: a systematic review and meta-analysis. BJOG. 2012;119(07):778-787. Doi: 10.1111/j.1471-0528.2012.03311.x

19 Di Lorenzo G, Ceccarello M, Cecotti V, Ronfani L, Monasta L, Vecchi Brumatti L, et al. First trimester maternal serum PIGF, free $\beta$-hCG, PAPP-A, PP-13, uterine artery Doppler and maternal history for the prediction of preeclampsia. Placenta. 2012;33(06):495-501. Doi: 10.1016/j.placenta.2012.03.003

20 Myatt L, Clifton RG, Roberts JM, Spong CY, Hauth JC, Varner MW, et al; Eunice Kennedy Shriver National Institute of Child Health and Human Development (NICHD) Maternal-Fetal Medicine Units (MFMU) Network. First-trimester prediction of preeclampsia in nulliparous women at low risk. Obstet Gynecol. 2012;119(06): 1234-1242. Doi: 10.1097/AOG.0b013e3182571669

21 Masoura S, Kalogiannidis IA, Gitas G, Goutsiolis A, Koiou E, Athanasiadis A, Vavatsi N. Biomarkers in pre-eclampsia: a novel approach to early detection of the disease. J Obstet Gynaecol. 2012;32(07):609-616. Doi: 10.3109/01443615.2012.709290

22 Espinoza J. Recent biomarkers for the identification of patients at risk for preeclampsia: the role of uteroplacental ischemia. Expert Opin Med Diagn. 2012;6(02):121-130. Doi: 10.1517/175300 59.2012.659726

23 Moore Simas TA, Crawford SL, Solitro MJ, Frost SC, Meyer BA, Maynard SE. Angiogenic factors for the prediction of preeclampsia in high-risk women. Am J Obstet Gynecol. 2007;197(03):244. e1-244.e8. Doi: 10.1016/j.ajog.2007.06.030

24 Erez O, Romero R, Espinoza J, Fu W, Todem D, Kusanovic JP, et al. The change in concentrations of angiogenic and anti-angiogenic factors in maternal plasma between the first and second trimesters in risk assessment for the subsequent development of preeclampsia and small-for-gestational age. J Matern Fetal Neonatal Med. 2008;21 (05):279-287. Doi: 10.1080/14767050802034545

25 Leaños-Miranda A, Campos-Galicia I, Isordia-Salas I, RiveraLeaños, Romero-Arauz, Ayala-Méndez JA, Ulloa-Aguirre A. Changes in circulating concentrations of soluble fms-like tyrosine kinase- 1 and placental growth factor measured by automated 
704 Evaluation of Angiogenic Factors (PIGF and sFlt-1) in Preeclampsia Diagnosis Sá et al.

electrochemiluminescence immunoassays methods are predictors of preeclampsia. J Hypertens. 2012;30(11):2173-2181. Doi: 10.1097/HJH.0b013e328 357c0c9

26 Verlohren S, Galindo A, Schlembach D, Zeisler H, Herraiz I, Moertl MG, et al. An automated method for the determination of the sFlt-1/ PIGF ratio in the assessment of preeclampsia. Am J Obstet Gynecol. 2010;202(02):161.e1-161.e11. Doi: 10.1016/j.ajog.2009.09.016

27 Hagmann H, Thadhani R, Benzing T, Karumanchi SA, Stepan H. The promise of angiogenic markers for the early diagnosis and prediction of preeclampsia. Clin Chem. 2012;58(05):837-845. Doi: 10.1373/clinchem.2011.169094

28 Zeisler H, Llurba E, Chantraine F, Vatish M, Staff AC, Sennström M, et al. Predictive value of the sFlt-1:PlGF ratio in women with suspected preeclampsia. N Engl J Med. 2016;374(01):13-22. Doi: 10.1056/NEJMoa1414838

29 Stepan H, Herraiz I, Schlembach D, Verlohren S, Brennecke S, Chantraine $\mathrm{F}$, et al. Implementation of the sFlt-1/PIGF ratio for prediction and diagnosis of pre-eclampsia in singleton pregnancy: implications for clinical practice. Ultrasound Obstet Gynecol. 2015;45(03):241-246. Doi: 10.1002/uog.14799

30 Smith GCS, Crossley JA, Aitken DA, Jenkins N, Lyall F, Cameron AD, et al. Circulating angiogenic factors in early pregnancy and the risk of preeclampsia, intrauterine growth restriction, spontaneous preterm birth, and stillbirth. Obstet Gynecol. 2007;109(06): 1316-1324. Doi: 10.1097/01.AOG.0000265804.09161.0d

31 Srinivas SK, Larkin J, Sammel MD, Appleby D, Bastek J, Andrella CM, et al. The use of angiogenic factors in discriminating preeclampsia: are they ready for prime time? J Matern Fetal Neonatal Med. 2010; 23(11):1294-1300. Doi: 10.3109/14767051003677988

32 Widmer M, Villar J, Benigni A, Conde-Agudelo A, Karumanchi SA, Lindheimer M. Mapping the theories of preeclampsia and the role of angiogenic factors: a systematic review. Obstet Gynecol. 2007; 109(01):168-180. Doi: 10.1097/01.AOG.0000249609.04831.7c

33 Scazzocchio E, Figueras F. Contemporary prediction of preeclampsia. Curr Opin Obstet Gynecol. 2011;23(02):65-71. Doi: 10.1097/ GCO.0b013e328344579c

34 Martins-Costa SH, Vettorazzi J, Valério E, Maurmann C, Benevides $\mathrm{G}$, Hemessath $\mathrm{M}$, et al. Protein creatinine ratio in random urine sample of hypertensive pregnant women: maternal and perinatal outcomes. Hypertens Pregnancy. 2011;30(03):331-337. Doi: 10.3109/10641950903454564

35 Papanna R, Mann LK, Kouides RW, Glantz JC. Protein/creatinine ratio in preeclampsia: a systematic review. Obstet Gynecol. 2008; 112(01):135-144. Doi: 10.1097/AOG.0b013e3181778cfc

36 Morris RK, Riley RD, Doug M, Deeks JJ, Kilby MD. Diagnostic accuracy of spot urinary protein and albumin to creatinine ratios for detection of significant proteinuria or adverse pregnancy outcome in patients with suspected pre-eclampsia: systematic review and meta-analysis. BMJ. 2012;345:e4342. Doi: 10.1136/ bmj.e4342

37 Narkiewicz K. Obesity and hypertension-the issue is more complex than we thought. Nephrol Dial Transplant. 2006;21(02): 264-267. Doi: 10.1093/ndt/gfi290 